\title{
What Determines Price-to-Earnings Ratios: An Empirical Evidence from Banking Sector of Pakistan
}

\author{
SAFDAR HUSSAIN TAHIR \\ Assistant Professor, Banking and Finance \\ Government College University Faisalabad, Pakistan \\ safdartahir@gmail.com \\ MUHAMMAD RIZWAN ULLAH \\ MS-Scholar, Department of Banking \& Finance, \\ Government College University Faisalabad, Pakistan \\ rizwan_muhammad32@yahoo.com \\ DR. SAID SHAH \\ Assistant Professor, Department of Management Sciences \\ University of Swabi, KPK, Pakistan \\ saidshah64@yahoo.com \\ Abstract \\ It is of greater importance to understand the factors influencing $P / E$ ratio for the \\ fund managers, decision makers, market analysts and individual investors. Variability in \\ shares prices and investment opportunities in Pakistani listed banking firms motivate to \\ examine the determinants of $P / E$ ratio using time-series as well as panel data analysis for \\ the period of 2007 to 2014. The findings of panel data indicate significant variation in \\ P/E ratio due to MktRtrn, VMP and SIZE. DP ratio is found to be the most influential \\ determinant of $P / E$ ratio indicating the willingness of investors to invest more funds in \\ those banking firms paying greater dividends. Empirical outcomes of time-series analysis \\ for banking industry represent that DP ratio is the super most imperative determinant of \\ $P / E$ ratio. Findings also indicate that $P / E$ ratio vary across years and influence the \\ investor's investment decision. The findings of the study facilitate the decision makers by \\ investigating the most significant determinant of P/E ratio of banking firms in order to \\ attract attention of investors and increase their confidence to choose these firms in their \\ portfolios. \\ Keywords: Price-to-Earnings ratio, Market Volatility, Karachi Stock Exchange, Banking \\ Industry.

\section{Introduction} \\ Extensive debate has been conducted on evaluating the performance of stock- \\ market by using various financial ratios like; price to sales ratio, price to earnings ratio \\ (P/E ratio), book to market ratio and price to dividend ratio (Bodie et. el., 2002). Though, \\ market analyst, investors, researchers and fund managers generally put their faith in price \\ to earnings ratio for evaluating equity investments' attractiveness and consider it as an \\ evaluation tool for analyzing individual stocks' performance (Molodovsky 1953). P/E \\ ratio, measured as dividing stock price by earnings per share, also known as "Price
}


Earnings Multiples", represents the degree of willingness of firms' investors to pay for every paisa of firms' earnings. Additionally, it reflects confidence and sentiment of investor about future performance of firm and effects investment decision. Theorists, concentrating on volatility of stock price, identified that $\mathrm{P} / \mathrm{E}$ ratio of markets and individual stocks portray changeability with time, showing that markets of stock had been plastering ridiculous pricing, financial bubbles and speculation. Consequently, the investors are having different techniques of estimation to recognize whether or not the market of stock is rationally priced. Quantitative studies tried scrutinizing the P/E ratio's determinants, to describe the factors affecting P/E ratio and finally the self-confidence of investors towards companies in order to make investment decisions.

Previous researchers has investigated the determinants of $\mathrm{P} / \mathrm{E}$ ratio using different proxies of dividend payout, discount rate, growth and risk in developed nations (White, 2000; Shamsuddin and Hiller, 2004 and Dudney et el., 2008). Though, some authors have investigated the determinants affecting P/E ratio in developing nations (Ramcharran, 2002 and Kumar and Warne 2009). Moreover, to the extent of firmspecific determinants of $\mathrm{P} / \mathrm{E}$, some analysts have analyzed the year, sector and size effects (Anderson and Brooks, 2006 and Kumar and Warne, 2009). In Pakistan context, no study has analyzed the firm-specific P/E ratio's determinants, whereas controlling the effects of size, year and sector. The Pakistan's shares market is an emerging market and stayed extremely volatile in the last decades. The KSE-100 index displayed an increasing movement from the period of 2005 through 2007 and touched it's highest on April 20, 2008 at 15,675 points. But the increasing trend discontinued because of worldwide financial crisis due to Pakistan's increasing political instability. Together with diminishing situations of economy which directed to severe decrease in prices of stock and stock market closed on $30^{\text {th }}$ December 2008 at 5,865 points. This decreasing trend of market of stock sustained in the period of 2009 but investors stayed unwilling investing in the stock markets (Economic survey of Pakistan 2009).

During the period of July, 2014 to March, 2015, commercial banks have distributed 326 billion rupees. This is 27.5 percent greater than the previous period in which banks have distributed 255.7 billion rupees. This made banks to be able achieving 65 percent of an annual target of 500 billion rupees. Net Foreign Assets, within broad money, of the banking industry raised and extended to 220.1 billion rupees in the period of July 2014 to May 2015 as compared to 243.7 billion rupees in the period of 2013 to 2014 (Economic survey of Pakistan 2014-15).

\subsection{Aim of the Study}

In overall stock market, $\mathrm{P} / \mathrm{E}$ ratio and share prices vary across sectors due to different prospects of growth, sectors having firms with stable, moderate and mature potential of growth have lesser P/E ratios as compared to sectors with fast-growing and fledgling firms (Anderson and Brooks, 2006). Therefore, present research analyzes P/E ratio of banking sector of Pakistan with the aim of recognizing the factors describing the deviations in $\mathrm{P} / \mathrm{E}$ ratio specific to banking sector.

\subsection{Contribution of the Study}

In Pakistan context, no study has analyzed the firm-specific $\mathrm{P} / \mathrm{E}$ ratio's determinants, whereas controlling the effects of size, year and sector. The Pakistan's shares market is an emerging market and stayed extremely volatile in the last decades. 
Consequently, the present study adds to the current debate in two ways: first, by analyzing the factors describing deviations in price-earnings $(\mathrm{P} / \mathrm{E})$ ratio of all banking firms listed in KSE of Pakistan for the period of 2007- 2014, and second, the time-series analysis of data has been carried out to diagnose the year effect on price-earnings $(\mathrm{P} / \mathrm{E})$ ratio of banking organizations.

\subsection{Significance of the Study}

The present study tries to help-out the decision as well as policy makers in ascertaining the substantial factors affecting the organization's P/E ratio. So that firms can attract investors' attention and can increase their sureness in order to select these companies in their portfolios.

\section{Review of Literature}

The association among share prices, dividends and book value per share and firm earnings has remained constantly as the focus interest of investors, analysts of market and managers of funds. Concerning this; the P/E ratio obtained massive admiration for analyzing market of stocks, sectors and individual stocks as latent hoards (Molodovskyy, 1953). The present debate has categorized the determinants of $\mathrm{P} / \mathrm{E}$ ratio according to market and sector analysis. Market analysis had been conducted by many scholars using different data and sample in developed as well as developing nations. These researchers found mixed evidence as regards the P/E ratio determinants. Numerous studies have scrutinized the P/E ratio's determinants for the economy of United States. Reilliy et al. (1983) have analyzed time-series association of $\mathrm{P} / \mathrm{E}$ ratio of 500 firms by using regression models for the period of 1963 through 1980. They observed that price-toearnings ratio enlarged with an upturn in dividend growth and dividend payout growth and declined with an inclination in risk-free rate, earnings volatility, inflation and business failure rate. Kane et el. (1996) have investigated a linkage amongst priceearnings ratio and volatility of market for 500 index of S\&P by using multiple regression models, the study covered the period of 1953-1994. They quantified that rate of inflation, detruded industrial production and market volatility had indirect and significant association with $\mathrm{P} / \mathrm{E}$ ratio, however the effect of dividend yield and real rate were found insignificant. Some quantitative researches have analyzed the P/E ratio's determinants by integrating sector, size and year effects. Anderson and Brooks (2006) highlighted, by using the financial data of all UK firms from 1975 through 2003, P/E ratios of firms also affected by three fundamental factors; industry effect, size of firm and the year in which price-earnings ratio is calculated. Alford (1992) has observed that on the industry basis, selection of firms described much of the variations in price-earnings ratios. Cho (1994) inspected the expounding influences of industry and size by categorizing, according to the nature of business, the firms into five sectors. He has used 1203 US firms as sample. Multiple regression outcomes illustrated that mining industry described the significant difference in earnings-price ratio and other sectors and size of firm had an indirect association with P/E ratio. Kumar and Warne (2009) conducted a sector and year-wise investigation of 243 firms registered at Bombay Stock Exchange, in multiple regression outcomes variations in size and market price were found to be the most important elements of price-earnings ratios for India's capital market.

In Pakistani context, Azam (2010) used the data of 35 firms registered in KSE of Pakistan from 2000 to 2008, and observed the impact of earnings growth, rate of discount 
and ratio of dividend payout on price-to-earning ratio. Regression outcomes showed that rate of interest had an indirect association with $\mathrm{P} / \mathrm{E}$ ratio and ratio of dividend payout and growth of earnings showed a direct association with price-earnings ratio. Though, in Pakistan, to the extent of the best knowledge of author, no research analyzed the price earnings ratio's determinants while controlling the effect of sector, firm size and year.

\section{Research Methodology}

The study uses, on balanced data, Ordinary Least Square (OLS) regression model to analyze the factors elucidating variations in P/E ratio of banking firms in Pakistan. The data from the period of 2007 through 2014 is analyzed. In order to calculate growth the period of 2006 is also included. 22 banking firms are selected as study sample. The study also conducted a time-series analysis in order to check the volatility in stock market to observe whether or not determinants of $\mathrm{P} / \mathrm{E}$ ratio vary across years. Data normality test (Kolmogorov-Smirnov test) is also applied to check the normality and suitability of regression techniques. The test showed that the data was normal and could be used further in regression analysis.

\subsection{Variables Description}

The description of all the variables used in this study is discussed below in Table 1:

\begin{tabular}{|c|c|c|c|}
\hline & Variable & & Description \\
\hline a. & Price-to-Earnings ratio $(\mathrm{P} / \mathrm{E})$ & & Share Price / Earnings Per Share \\
\hline b. & Dividend Payout (DP) & & Dividend Per Share / Earnings Per Share \\
\hline c. & Tobin’s Q (TQ) & & Total Market Value of Firm / Total Book Value of Assets \\
\hline $\begin{array}{l}\text { d. } \\
\text { e. }\end{array}$ & $\begin{array}{l}\text { Leverage (LEV) } \\
\text { Market Return (MktRtrn) }\end{array}$ & & $\begin{array}{l}\text { Total Debts / Total Assets } \\
\text { (Dividend + Change in Share Price) / Last year's Share } \\
\text { Price }\end{array}$ \\
\hline f. & $\begin{array}{l}\text { Variability in Market } \\
\text { (VMP) }\end{array}$ & Price & $\begin{array}{l}\text { Calculated as Standard Deviation of average of high and } \\
\text { low market prices }\end{array}$ \\
\hline g. & Earnings Growth (EG) & & $\begin{array}{l}\text { (Current year's Net Income - Last year's Net Income) / } \\
\text { Last year's Net Income }\end{array}$ \\
\hline h. & Corporate Size (SIZE) & & Measured as Natural Log of Total Assets \\
\hline
\end{tabular}

"Note: This table provides a brief description of all the variables used in the study"

\subsection{Empirical Design of Model}

The current research examines the determinants (dividend payout ratio, leverage, Tobin's Q, earnings growth, market return, variability in market prices and size) of priceearnings ratio.

There are two phases of empirical analysis: first; a regression analysis on the basis of balanced data and second; a time-series regression analysis by estimating a separate regression equation for each year.

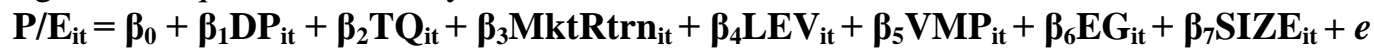

Where; $\quad$ P/E is Price-to-Earnings ratio, DP is Dividend Payout, TQ is Tobin's Q, MktRtrn is Market Return, LEV is Leverage, VMP is Variability in Market Price, EG is Earnings Growth, SIZE is Corporate Size of firm $i$ for time period $t$.

\section{Empirical Results and Discussions}

The study has explained the descriptive statistics, correlation analysis, panel data regression analysis and regression results of time-series analysis in this section. 


\subsection{Descriptive Statistics}

Table 2 illustrates the descriptive statistics of all the variables on the basis of data of all the banks listed in KSE of Pakistan. P/E ratio explains that investors are willing to pay, on average of 8.09 rupees against each rupee which shows the confidence of investors to invest in banking firms. The average of DP ratio is 0.13 with the maximum value of 2.01 and minimum value of -1.69 , the value of standard deviation is 0.33 . The mean value of leverage (LEV) indicates that the banking firms rely more on debts for financing their activities. The average value of market return (MktRtrn) is 15.73 with a higher value of standard deviation of 58.77, showing a highly volatile stock prices behavior during the period of study. The average value of earnings growth (EG) is 0.19 ranging from -11.86 to 20.32 . Size of firm on average is 8.24 large with the value of standard deviation of only 0.54 showing that the overall banking sector has large size firms.

\section{Table 2: Descriptive Statistics}

\begin{tabular}{l|c|ccc|c}
\hline Variables & $\mathbf{N}$ & Minimum & Maximum & Mean & Std. Deviation \\
\hline P/E & 198 & -261.75101 & 242.77778 & 8.094292 & 34.338781 \\
DP & 198 & -1.696125 & 2.019559 & 0.131844 & 0.331609 \\
TQ & 198 & 0.134726 & 15.030919 & 1.166988 & 1.386903 \\
LEV & 198 & 0.060311 & 11.984495 & 1.001377 & 1.10438 \\
MktRtrn & 198 & -0.219015 & 19.93311 & 15.73658 & 58.772031 \\
VMP & 198 & -0.865031 & 3.739336 & 0.063529 & 0.554391 \\
EG & 198 & -11.862443 & 20.322293 & 0.192975 & 2.441944 \\
SIZE & 198 & 6.604731 & 9.271145 & 8.24122 & 0.545382 \\
\hline
\end{tabular}

\subsection{Correlation Analysis}

The analysis of correlation is executed to scrutinize the association among all the study variables. Table 3 shows the coefficients of correlation; the problem of multicollinearity does not exist in the data because the variables under study are having value of correlation coefficient not greater than 0.63 .

Table 3: Pearson Correlation Matrix

\begin{tabular}{|c|c|c|c|c|c|c|c|c|}
\hline Variables & $\mathbf{P} / \mathbf{E}$ & DP & TQ & LEV & MktRtrn & VMP & EG & SIZE \\
\hline $\mathbf{P} / \mathbf{E}$ & 1.000 & & & & & & & \\
\hline DP & $0.634 * *$ & 1.000 & & & & & & \\
\hline TQ & 0.041 & -0.034 & 1.000 & & & & & \\
\hline LEV & 0.046 & -0.019 & $0.612 * *$ & 1.000 & & & & \\
\hline MktRtrn & -0.001 & $0.1708 *$ & -0.071 & -0.050 & 1.000 & & & \\
\hline VMP & $0.145^{*}$ & -0.026 & -0.012 & -0.024 & 0.125 & 1.000 & & \\
\hline EG & 0.005 & -0.018 & -0.008 & -0.006 & -0.016 & 0.025 & 1.000 & \\
\hline SIZE & $0.152 *$ & 0.038 & $-0.262 * *$ & $-0.252 * *$ & $0.182 * *$ & 0.091 & 0.019 & 1.000 \\
\hline
\end{tabular}

\subsection{Regression Results of Pooled Data Analysis}

The study uses OLS regression to analyze the impact of earnings growth (EG), dividend payout (DP) ratio, leverage (LEV), Tobin's Q (TQ), market returns (MktRtrn), variations in market prices (VMP) and firm size (SIZE) on P/E ratio for banking industry. Overall, $45 \%$ variations in response variable are explained by independent variables, as 
represented in adjusted $\mathrm{R}$ square and the model of the study is also significant at 0.01 levels of significance, the model also have no serial correlation problem, as the value of $\mathrm{D}-\mathrm{W}$ is 1.37 . Table 4 exhibits the regression outcomes of balanced data analysis on the basis of 198 observations for 22 banking firms. Results indicate that payout ratio, market returns, market price variability and size of firm meaningfully explain the deviations in $\mathrm{P} / \mathrm{E}$ ratio. The highest explanatory power is demonstrated by the dividend payout ratio (12.35), explaining the willingness of investors to pay more for banking firms paying higher dividends. Consistent with White (2000), 1 percent upturns in the DP ratio leads to rise 12 times in price-earnings ratio. The study finds a positive association between Variability in market price and price-earnings ratio, indicating that investors prefer those firm's shares having greater market prices volatility to get the capital gain benefits consisting with the outcomes of Kumar and Warne (2009). Tobin's Q does not affect the $\mathrm{P} / \mathrm{E}$ ratio rejecting the results of Cho (1994) and Zarowin (1990). Firm size indicates positive impact on $\mathrm{P} / \mathrm{E}$ ratio, showing that investors are highly willing to endow in the small banking firms supporting the outcomes of Baniz (1981) and Reiniganum (1981).

Table: 4. Regression Results of Pooled Data Analysis

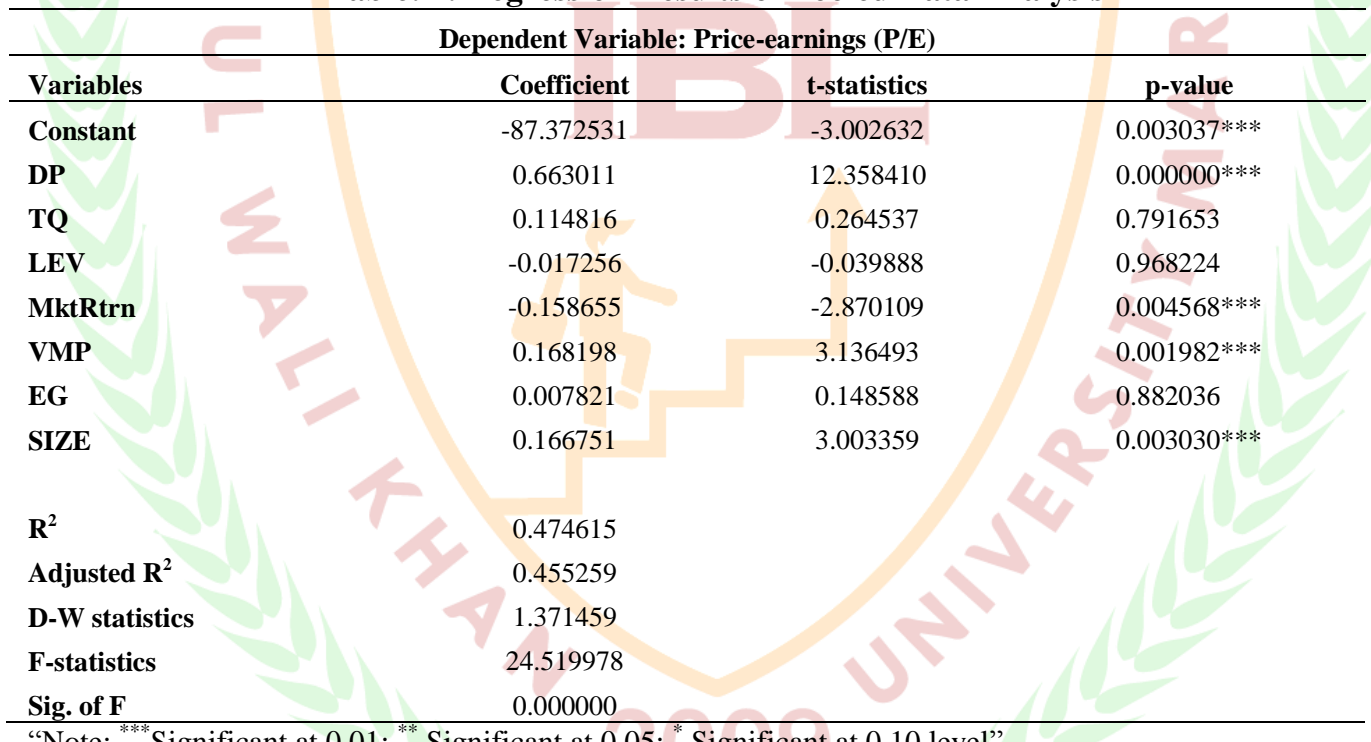

"Note: ${ }^{* * * *}$ Significant at $0.01 ;{ }^{* *}$ Significant at $0.05 ;{ }^{*}$ Significant at 0.10 level"

Moreover, leverage negatively affects the P/E ratio and EG positively influences P/E ratio, supporting the results of Beavier and Morsse (1978), Ramchharran (2002) and Jones (2000). The results indicates that greater leverage increases the cost of financial distress which leads to a lower price-earnings ratio, however greater EG counterbalance the impact of risk which leads to enhance the confidence of investors and thus the ratio of $\mathrm{P} / \mathrm{E}$. Lastly, market return has significant positive impact on P/Eratio at the significance level of 0.01 , as the firms having higher market return increases the confidence of investors to choose these banking firms in their portfolio. 


\subsection{Regression Results of time-series Analysis}

Considering greater volatility in Pakistan's stock market in the period of study, a time-series data analysis has also been taken in to account using OLS regression to analyze whether or not price-earnings ratio's determinants vary across years? All the Models for each year are significant statistically at $0.01,0.05$ and 0.10 levels and D-W value shows no serial correlation in time-series data. Adjusted $\mathrm{R}$ squares of time-series analysis are higher than adjusted $\mathrm{R}$ square of balanced panel data analysis, showing that the explanatory power of determinants of P/E ratio is increased during the analysis of time series data.

Table 5: Regression Outcomes of cross-section Analysis of Banking Sector

\begin{tabular}{|c|c|c|c|c|c|c|c|c|}
\hline Variable & 2007 & 2008 & 2009 & 2010 & 2011 & 2012 & 2013 & 2014 \\
\hline \multirow[t]{2}{*}{ Constant } & $-99.8 * * *$ & -54.64 & -89.14 & -18.12 & 15.21 ** & -32.88 & $94.21 * * *$ & -22.12 \\
\hline & $(0.00)$ & $(0.65)$ & $(0.11)$ & $(0.87)$ & $(0.03)$ & $(0.84)$ & $(0.01)$ & $(0.74)$ \\
\hline \multirow[t]{2}{*}{ DP } & $42.53 * * *$ & $0.53 * *$ & $0.70 * * *$ & 0.32 & $0.60^{* * *}$ & 0.64 & 0.39 & $0.73 * * *$ \\
\hline & $(0.00)$ & $(0.03)$ & $(0.00)$ & $(0.14)$ & $(0.00)$ & $(0.11)$ & $(0.14)$ & $(0.00)$ \\
\hline \multirow[t]{2}{*}{ TQ } & 49.93 & -0.15 & -0.10 & -0.31 & 0.36 & 0.49 & -0.06 & 0.20 \\
\hline & $(0.14)$ & $(0.70)$ & $(0.70)$ & $(0.51)$ & $(0.11)$ & $(0.14)$ & $(0.84)$ & $(0.18)$ \\
\hline \multirow[t]{2}{*}{ LEV } & -53.79 & 0.11 & -0.05 & 0.15 & $-0.529 * *$ & -0.03 & $-0.558 *$ & -0.14 \\
\hline & $(0.20)$ & $(0.80)$ & $(0.85)$ & $(0.78)$ & $(0.02)$ & $(0.93)$ & $(0.08)$ & $(0.31)$ \\
\hline \multirow[t]{2}{*}{ MktRtrn } & $-0.00 *$ & -0.19 & -0.20 & -0.21 & $-0.65 * * *$ & -0.54 & -0.39 & -0.18 \\
\hline & $(0.06)$ & $(0.45)$ & $(0.30)$ & $(0.48)$ & $(0.00)$ & $(0.19)$ & $(0.23)$ & $(0.17)$ \\
\hline \multirow[t]{2}{*}{ VMP } & 30.27 & -0.12 & -0.22 & -0.08 & $0.20 * *$ & 0.01 & 0.04 & $0.45^{* * *}$ \\
\hline & (0.19) & $(0.63)$ & $(0.34)$ & $(0.83)$ & $(0.03)$ & $(0.97)$ & $(0.89)$ & $(0.00)$ \\
\hline \multirow[t]{2}{*}{ EG } & $5.86^{*}$ & -0.12 & -0.02 & 0.44 & -0.07 & -0.11 & 0.13 & $0.20 *$ \\
\hline & $(0.09)$ & $(0.65)$ & $(0.89)$ & $(0.14)$ & (0.39) & $(0.65)$ & $(0.52)$ & $(0.10)$ \\
\hline \multirow[t]{2}{*}{ SIZE } & $44.90 * * *$ & 0.27 & $0.54 * *$ & 0.18 & -0.06 & -0.31 & -0.20 & 0.04 \\
\hline & $(0.00)$ & $(0.42)$ & $(0.02)$ & $(0.55)$ & $(0.54)$ & $(0.34)$ & $(0.42)$ & $(0.71)$ \\
\hline $\mathbf{R}^{2}$ & 0.87 & 0.38 & 0.68 & 0.48 & 0.91 & 0.34 & 0.56 & 0.84 \\
\hline Adj. $R^{2}$ & 0.80 & 0.08 & 0.52 & 0.22 & 0.87 & 0.01 & 0.33 & 0.76 \\
\hline D-W stat. & 2.20 & 2.57 & 2.58 & 1.35 & 2.36 & 1.90 & 2.19 & 2.20 \\
\hline F-stat. & 13.02 & 1.25 & 4.24 & 1.87 & 20.64 & 1.04 & 2.50 & 10.69 \\
\hline Sig. of $\mathbf{F}$ & 0.00 & 0.34 & 0.01 & 0.15 & 0.00 & 0.45 & 0.07 & 0.00 \\
\hline
\end{tabular}

Table 5 reports the results of time-series analysis for banking industry, showing that DPratio is the super most significant determinant of P/Eratio, as their values of coefficients are highest and significant statistically in the periods of 2007, 2008, 2009, 2011 and 2014 supporting to past results. Variation in market price has positive association with price-earnings ratio in the periods of 2007, as KSE 100 index presented an increasing trend in 2007. During 2008 market of stocks has been sharply declined and remained constant for four months that is from August 27, 2008 to December 12, 2008, 
this descending variability of stock prices decreases the investors' confidence leading to negative impact on P/E ratios for the period of 2008. Impact of market return on P/E ratio is found significant negative in 2007 and 2011. There is significant positive association between SIZE and P/E ratio for the study period of 2007 and 2009. The impact of leverage on P/E ratio is found significantly negative in 2011 and 2013 study period. Earnings growth is found significant positive determinant only in the periods of 2007 and 2014. However; the coefficients of Tobin's Q are found insignificant in all the years of study period.

\section{Conclusion}

It is of greater importance to understand the factors influencing P/E ratio for the managers of funds, decision makers, analysts of market and individual investors as the valuation of equity is of vital importance in order to make investment decision. Variability in shares prices and opportunities of investment in Pakistani listed banking firms motivate to examine the determinants of $\mathrm{P} / \mathrm{E}$ ratio using time-series as well as panel data analysis. The findings of panel data indicate significant variation in $\mathrm{P} / \mathrm{E}$ ratio due to market return, market price variations and corporate size. DP ratio is found to be the most influential determinant of $\mathrm{P} / \mathrm{E}$ ratio indicating the willingness of investors to invest more funds in banking firms paying greater dividends. There is direct association between variability in market price and $\mathrm{P} / \mathrm{E}$ ratio, indicating that investors prefer those firm's shares having high variability in market prices in order to get higher capital gains. Firm size indicates a positive effect on $\mathrm{P} / \mathrm{E}$ ratio, showing that shareholders are highly enthusiastic towards investing in banking firms. Empirical outcomes of time-series analysis for banking industry represent that DP ratio is the super most imperative determinant of $\mathrm{P} / \mathrm{E}$ ratio. Findings also indicate that $\mathrm{P} / \mathrm{E}$ ratio vary across years and influence the investor's investment decision.

\subsection{Policy Implications and Suggestions}

- The findings of the study facilitate the decision makers, researchers as well as academicians by investigating the most significant determinants of $\mathrm{P} / \mathrm{E}$ ratio of banking firms.

- The findings also help investors making decisions regarding investment portfolios.

- Higher dividends should be paid to the stockholders by the banking firms to raise the investor's confidence.

- Likewise, a decrease in leverage and increase in return of market and earnings growth is necessary to get the attention of investors and to enhance their confidence to choose these banking firms in their portfolios.

\subsection{Limitations and Future Directions}

- Current research is restricted to the investigation of $\mathrm{P} / \mathrm{E}$ ratio's determinants of banking industry; future researchers could identify these determinants of other stock market of Pakistan.

\section{References}

Alford, A. (1992). The Effect of the Set of Comparable Firms on the Accuracy of the Price-Earnings Valuation Method. Journal of Accounting Research, Vol. 94, pp.94-108. 
Anderson, K. \& Brooks, C. (2006). Decomposing the Price-Earnings Ratio. Journal of Asset Management, Vol.6(6), pp.456-469.

Azam, M. (2010). Factors Influencing the Price-earnings Multiples and Stock values in the Karachi stock exchange. Interdisciplinary Journal of Contemporary Research in Business, 2(5), 105.

Banz, R. (1981). The Relationship between Returns and Market Value of Common Stocks, Journal of Financial Economics, Vol.12, pp.129-156.

Beaver, W. \& Morse, D. (1978). What Determines Price-Earnings Ratios? Financial Analysts Journal, Vol.34, No.4, pp. 65-76.

Bodie, Z., Kane, S. A. \&Marcus, A. (2002). Investment 5th. Ed, McGraw-Hill Companies, INC.

Cho, Y. J. (1994). Determinants of Earnings-Price Ratios: A Reexamination. Review of Financial Economics, 3(2), 105-120.

Dudney, D., Jirasakuldech, B. \& Zorn, T. (2008). Return Predictability and the P/E Ratio: Reading the Entrails. The Journal of Investing, pp.75-82.

Economic Survey of Pakistan. (2008-09). Finance Division, Government of Pakistan. http://www.finance.gov.pk/survey_0809.html

Economic Survey of Pakistan. (2014-15). Finance Division, Government of Pakistan. http://www.finance.gov.pk/survey/chapters_15/Highlights.pdf

Gordon, M. \& Shapiro, E. (1956). Capital Equipment Analysis: The Required Rate of Profit. Management Science, Vol. 3, pp. 102-112.

Jones, C. P. (2000). Investments: Analysis and Management. 7th ed. John Wiley \& Sons Inc, New York.

Kane, A., Marcus, A. \& Noh, J. (1996). The P/E Multiple and Market Volatility. Financial Analysts Journal, Vol.52(4), pp.16-24.

Kumar, S., \& Warne, D. P. (2009). Parametric Determinants of Price-Earnings Ratio in Indian Capital Markets. The ICFAI Journal of Applied Finance, Vol.15(9), pp.6382.

Molodovsky, N. (1953). A Theory of Price-Earnings Ratios. Financial Analysts Journal, Vol.51(1), pp.29-43.

Ramcharran, H. (2002). An empirical analysis of the determinants of the P/E ratio in emerging markets. Emerging Markets Review, Vol.3(2), pp.165-178.

Reilly, F. K., Griggs, F. T., \& Wong, W. (1983). Determinants of the aggregate stock market earnings multiple. Journal of Portfolio Management, Vol. 1(1), pp.36-45.

Reinganum, M. (1981). Misspecification of Capital Asset Pricing: Empirical Anomalies Based on Earnings Yield and Market Values. Journal of Financial Economics, Vol.9, pp.19-46.

Shamsuddin, A. \& Hiller, A. J. (2004). Fundamental determinants of the Australian priceearnings multiple. Pacific-Basin Finance Journal, Vol.12(5), pp. 565-576.

White, C. B. (2000). What P/E will the U.S Stock Market Support? Financial Analysts Journal, Vol.56(6), pp.30-38.

Zarowin, P. (1990). What determines earnings price ratios: revisited. J. of Acc. Audit. Finance, Vol. 5(25), pp 439-457 